\title{
Basalts erupted along the Tongan fore arc during subduction initiation: Evidence from geochronology of dredged rocks from the Tonga fore arc and trench
}

\author{
Sebastian Meffre, Trevor J. Falloon, and Tony J. Crawford \\ ARC Centre of Excellence in Ore Deposits and School of Earth Sciences, University of Tasmania, \\ Private Bag 79, Hobart, Tasmania 7001, Australia (smeffre@utas.edu.au; trevor.falloon@utas.edu.au; \\ tony.crawford@utas.edu.au)
}

Kaj Hoernle and Folkmar Hauff

GEOMAR, Helmholtz Centre for Ocean Research Kiel, Wischhofstrasse 1-3, DE-24148 Kiel, Germany (khoernle@geomar.de; fhauff@geomar.de)

\author{
Robert A. Duncan \\ College of Earth, Ocean and Atmospheric Sciences, Oregon State University, Corvallis, Oregon \\ 97331-5506, USA \\ Department of Geology and Geophysics, King Saud University, Riyadh 11451, Saudi Arabia \\ (rduncan@coas.oregonstate.edu)
}

\author{
Sherman H. Bloomer and Dawn J. Wright \\ College of Earth, Ocean and Atmospheric Sciences, Oregon State University, Corvallis, Oregon \\ 97331-5506, USA (sherman.bloomer@oregonstate.edu; dawn@dusk.geo.orst.edu)
}

[1] A wide variety of different rock types were dredged from the Tonga fore arc and trench between 8000 and $3000 \mathrm{~m}$ water depths by the 1996 Boomerang voyage. ${ }^{40} \mathrm{Ar}-{ }^{39} \mathrm{Ar}$ whole rock and U-Pb zircon dating suggest that these fore arc rocks were erupted episodically from the Cretaceous to the Pliocene (102 to $2 \mathrm{Ma}$ ). The geochemistry suggests that MOR-type basalts and dolerites were erupted in the Cretaceous, that island arc tholeiites were erupted in the Eocene and that back arc basin and island arc tholeiite and boninite were erupted episodically after this time. The ages generally become younger northward suggesting that fore arc crust was created in the south at around 48-52 Ma and was extended northward between 35 and $28 \mathrm{Ma}$, between 9 and $15 \mathrm{Ma}$ and continuing to the present-day. The episodic formation of the fore arc crust suggested by this data is very different to existing models for fore arc formation based on the Bonin-Marianas arc. The Bonin-Marianas based models postulate that the basaltic fore arc rocks were created between 52 and $49 \mathrm{Ma}$ at the beginning of subduction above a rapidly foundering west-dipping slab. Instead a model where the $52 \mathrm{Ma}$ basalts that are presently in a fore arc position were created in the arc-back arc transition behind the 57-35 Ma Loyalty-Three Kings arc and placed into a fore arc setting after arc reversal following the start of collision with New Caledonia is proposed for the oldest rocks in Tonga. This is followed by growth of the fore arc northward with continued eruption of back arc and boninitic magmas after that time. 
Components: 8600 words, 10 figures, 3 tables.

Keywords: Tonga; U-Pb geochronology; back-arc basin basalts; fore arc; subduction-related magma genesis; trench.

Index Terms: 1115 Geochronology: Radioisotope geochronology; 3075 Marine Geology and Geophysics: Submarine tectonics and volcanism; 3619 Mineralogy and Petrology: Magma genesis and partial melting (1037).

Received 11 July 2012; Revised 23 October 2012; Accepted 26 October 2012; Published 7 December 2012.

Meffre, S., T. J. Falloon, T. J. Crawford, K. Hoernle, F. Hauff, R. A. Duncan, S. H. Bloomer, and D. J. Wright (2012), Basalts erupted along the Tongan fore arc during subduction initiation: Evidence from geochronology of dredged rocks from the Tonga fore arc and trench, Geochem. Geophys. Geosyst., 13, Q12003, doi:10.1029/2012GC004335.

\section{Introduction}

[2] The Pacific island arc systems are often used as analogues for understanding both subduction-related island arc magmatic rocks and ophiolitic rocks incorporated in older fold belts so a thorough understanding of the evolution of these modern systems is not only of local interest but is important for understanding island arc-related evolution worldwide. Both the Tonga-Kermadec and the Bonin-Mariana systems are thought to represent typical intraoceanic island arcs systems that have evolved with very little influence from the continents [Hawkins et al., 1984]. In this study we present new age and geochemical data on Cretaceous to Miocene rocks from the Tonga fore arc which place some constraints on the early history of this system. The early history of active intraoceanic island arc systems is very difficult to unravel as the rocks tend to be submerged and deeply buried beneath younger rocks. One place where early arc rocks are exposed is on the trench walls where erosion caused by the subducting plate often exposes older rocks [Hawkins et al., 1984; Stern and Bloomer, 1992]. The rocks in these environments are generally volcanic dominated, which makes biostratigraphic dating difficult, as well as mafic with low concentrations of radioactive elements such as $\mathrm{U}, \mathrm{K}$ or $\mathrm{Rb}$, making them difficult to date using radiometric methods. This has hampered our understanding of the early history of these rocks.

[3] At present much of what we know about the early history of these arcs originates from the BoninMariana system (see review by Reagan et al. [2010]). The early Tertiary rocks from the Tonga system, $6000 \mathrm{~km}$ to the southeast, have received much less attention. In this study we present the results of whole rock geochemistry and ${ }^{40} \mathrm{Ar}-{ }^{39} \mathrm{Ar}$ and $\mathrm{U}-\mathrm{Pb}$ geochronology on rocks dredged from the Tonga fore arc. The aims are threefold: (1) to gain more information about events which occur during the initiation of subduction; (2) to further constrain the tectonic reconstruction of the SW Pacific; and (3) to compare and contrast the Bonin-Mariana system to the north and to investigate possible links in terms of subduction initiation, tectonic evolution and magmatic processes.

[4] The 1996 voyage of the R/V Melville from the Scripps Institution of Oceanography (Boomerang Cruise, Leg 8) sampled traverses along the Tonga trench (Figure 1) to gather site survey data for possible ocean drilling [Bloomer and Wright, 1996]. Preliminary results from the voyage were presented by Bloomer et al. [1996], Wright et al. [1996] and Tappin [1996]. Samples recovered from the trench walls preserve a cross-section of the oceanic crust beneath Tonga with peridotite at the base $(6000$ $9000 \mathrm{~m})$, gabbros and dolerite in the middle and volcanic rocks at the shallow dredge sites $(<4500 \mathrm{~m})$ with one exception near ODP site 841, where tectonic erosion by the Louisville Ridge has downfaulted Miocene sedimentary rock to the base of the trench. The geochemistry of selected volcanic rocks recovered from the voyage have been presented by Falloon et al. [1997], Falloon et al. [2007] (dredges 114-120), and Falloon et al. [2008] (dredge 113), and the mineralogy and alteration of gabbros, plagiogranites and basalts have been presented by Kelman [1998], Banerjee et al. [2000] (dredges 96, 99, 102, 108 and 113) and Banerjee and Gillis [2001] (dredges 94, 96, 99, 101, 105, 106, 108, 111-113). Clift et al. [1998] and Wright et al. [2000] discuss the tectonics and topography of the Tonga trench and fore arc based on the voyage results. Bloomer et al. [1998] presented preliminary ${ }^{40} \mathrm{Ar}-{ }^{39} \mathrm{Ar}$ age data from the voyage dredge sites and Sack et al. [2011] dated Miocene basalts from two Tonga dredge sites (dredge 107, sample 107-1-7 and dredge 111, sample 111-4-6) as part of the method development for dating small in situ zircon in basalt and dolerites. 


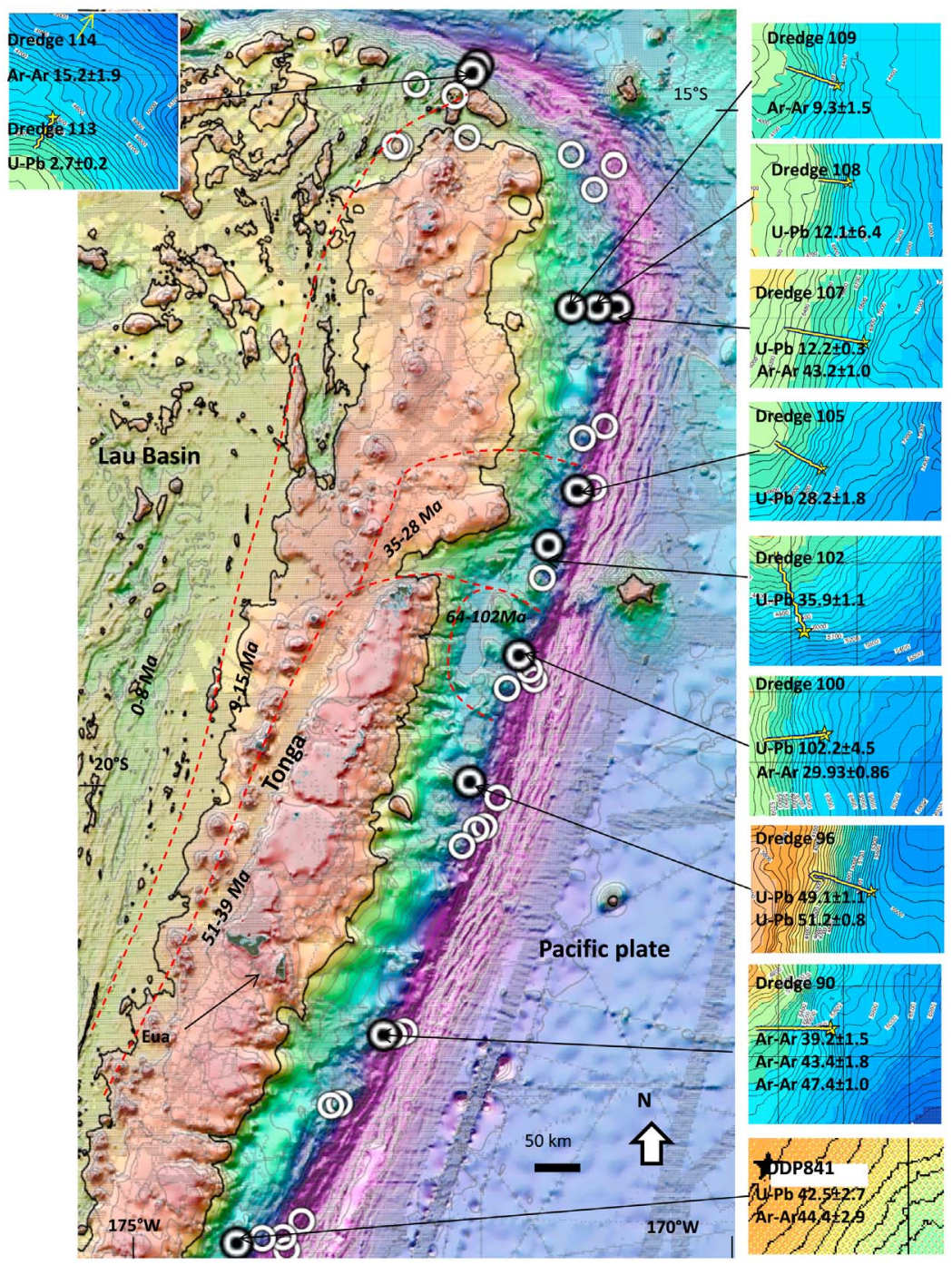

Figure 1. Location of the dredges (open circles) showing detailed bathymetry of each of the sites with radiometric dates (closed circles). Thin black lines on the detailed bathymetric maps are $10 \mathrm{~min}$ of latitude and longitude. Base map image from Becker et al. [2009] detailed site localities from Wright et al. [2000] and http://buccaneer.geo.orst. edu/dawn/tonga/.

[5] The analysis and interpretation of the results presented here, particularly with regards to the geochemistry, is just at a very preliminary stage. However, given the large time difference between the ages of the various rock types and the fact that only a few of the dredges were actually dated, significant inferences have to be made when discussing the geochemistry. Each dredge could incorporate rocks formed from a number of different periods so that detailed analysis of the geochemistry runs the risk that rocks from a number of different periods are incorporated into a single geochemical grouping leading to misinterpretation of the results. For this reason, we have left the geochemical interpretation to a minimum and hope that a detailed investigation will be undertaken in the future when more dates become available.

\section{Methods}

[6] The samples examined as part of this study are the fore arc dredges (Sites 81 to 114) from the 1996 Melville voyage. Representative rocks from each of the dredges were thin sectioned and examined in detail prior to selecting samples for major and trace element geochemistry. Volcanic rocks were then selected for ${ }^{40} \mathrm{Ar}-{ }^{39} \mathrm{Ar}$ incremental heating 
experiments. The ${ }^{40} \mathrm{Ar}-{ }^{39} \mathrm{Ar}$ analyses was performed on least-altered whole rock samples in late 1997 and early 1998 [Bloomer et al., 1998] at the Oregon State University using methods similar to those of Koppers et al. [2004]. The ${ }^{40} \mathrm{Ar}-{ }^{39} \mathrm{Ar}$ dating results were very difficult to interpret and to relate to the geochemistry. The obvious $\mathrm{K}$ mobility in the geochemistry suggested that the ${ }^{40} \mathrm{Ar}-{ }^{39} \mathrm{Ar}$ data may not be entirely representative of the initial eruption and could have been in part reset during latter events. Between 2004 and 2008 some of the rocks where analyzed for $\mathrm{U}-\mathrm{Pb}$ zircon geochronology partially using a conventional laser ablation technique and partially using an experimental in situ technique. Preliminary results were reported at a conference in 2007 [Meffre and Falloon, 2007]. Publication of the results then waited for testing and publication of the methodology of the technique until 2012.

[7] The rocks from each dredge were analyzed using standard X-ray fluorescence (XRF) techniques and inductively coupled mass spectrometry (ICPMS) for low level trace elements and rare earths (techniques are reported in detail by Falloon et al. [2007]).

[8] Basalts, rhyolites, dolerites and gabbros from 17 of the 32 dredge sites were chosen for U-Pb geochronology. Two additional samples were processed from rhyolitic volcaniclastic rocks at the base of ODP $841 \mathrm{~B}$ to check the accuracy of the existing ${ }^{40} \mathrm{Ar}-{ }^{39} \mathrm{Ar}$ data [McDougall, 1994]. Polymict rhyolitic volcaniclastic rocks were deliberately chosen to increase the chances of encountering different types of clasts which could contain zircons. The U-Pb geochronology was performed using two techniques. The small zircon technique uses automated scanning electron microscopy (SEM) to locate small zircons (10$20 \mu \mathrm{m})$ that are relatively common in polished rock mounts of basalts, dolerites and gabbros. These are then analyzed on the laser ICPMS in situ using $10 \mu \mathrm{m}$ spot sizes. This technique is very useful for dredge samples such as those studied here because only small samples are required with minimal sample preparation or possible sources of sample contamination. However, the technique is less precise than conventional laser ICPMS technique due to the low intensity of the signal and the increased chances of encountering zones with Pb loss [Sack et al., 2011]. In this study two overnight runs were programmed on the automated SEM with 8 out of 20 rocks containing zircons large enough to be dated.

[9] The other $\mathrm{U}-\mathrm{Pb}$ technique used is the standard laser ICPMS technique on zircons from mineral separates and is suitable for mafic to intermediate coarse-grained and felsic samples where zircons have time to grow during magmatic differentiation. This technique is described in detail by Sack et al. [2011] and a brief summary is given here. The rocks were crushed to a coarse sand in a chrome steel ring mill, extracting non-magnetic heavy minerals using a gold pan and a hand magnet, picking the crystals under a microscope and mounting them in an epoxy mount prior to polishing and analysis. The crystals are then ablated using a $30 \mu \mathrm{m}$ spot using a laser pulsing at $5 \mathrm{~Hz}$ in a $\mathrm{He}$ atmosphere. Most of the samples were analyzed using a $213 \mathrm{~nm}$ New Wave laser and an HP 4500 ICPMS. A few samples were analyzed using a $193 \mathrm{~nm}$ solid state laser (New Wave) and an Agilent 7500cs ICPMS. Data reduction and uncertainty propagation was performed in a similar way to Sack et al. [2011] using the Temora standard of Black et al. [2003] as the primary standard and the 91500 zircons of Wiedenbeck et al. [1995] as the secondary standard. The weighted average of both the primary and secondary standards analyzed within the analytical runs were always within the 2 sigma analytical uncertainty relative to the published values (see Table S1 in the auxiliary material). ${ }^{1}$

\section{Results}

\subsection{Petrography}

[10] The unaltered primary mineralogy of the samples is summarized in Table S2. The alteration of the dredge samples is discussed by Banerjee and Gillis [2001].

\subsection{Geochemistry}

[11] The geochemistry of rocks dated in this study is presented in Table S2. In Table S2 we also include additional analyses of representative rocks from $25^{\circ}$ to $14^{\circ} \mathrm{S}$ along the Tonga fore arc and trench. The geochemistry of these rocks will be discussed within the context of our more extensive data set from the Tonga fore arc which is displayed in Figures 2-7. Our complete geochemical data set will be presented in detail elsewhere. The majority of the rocks recovered were tholeiitic basalts and dolerites ranging between 50 and $55 \mathrm{wt} \% \mathrm{SiO}_{2}$ and 5 to $9 \mathrm{wt} \% \mathrm{MgO}$. Approximately half of the dredges also contained significant amounts of boninite, peridotite, gabbro and minor amounts of rhyolite, plagiogranite and volcaniclastic rocks (Figure 2).

\footnotetext{
${ }^{1}$ Auxiliary materials are available in the HTML. doi:10.1029/
} $2012 \mathrm{GC} 004335$. 


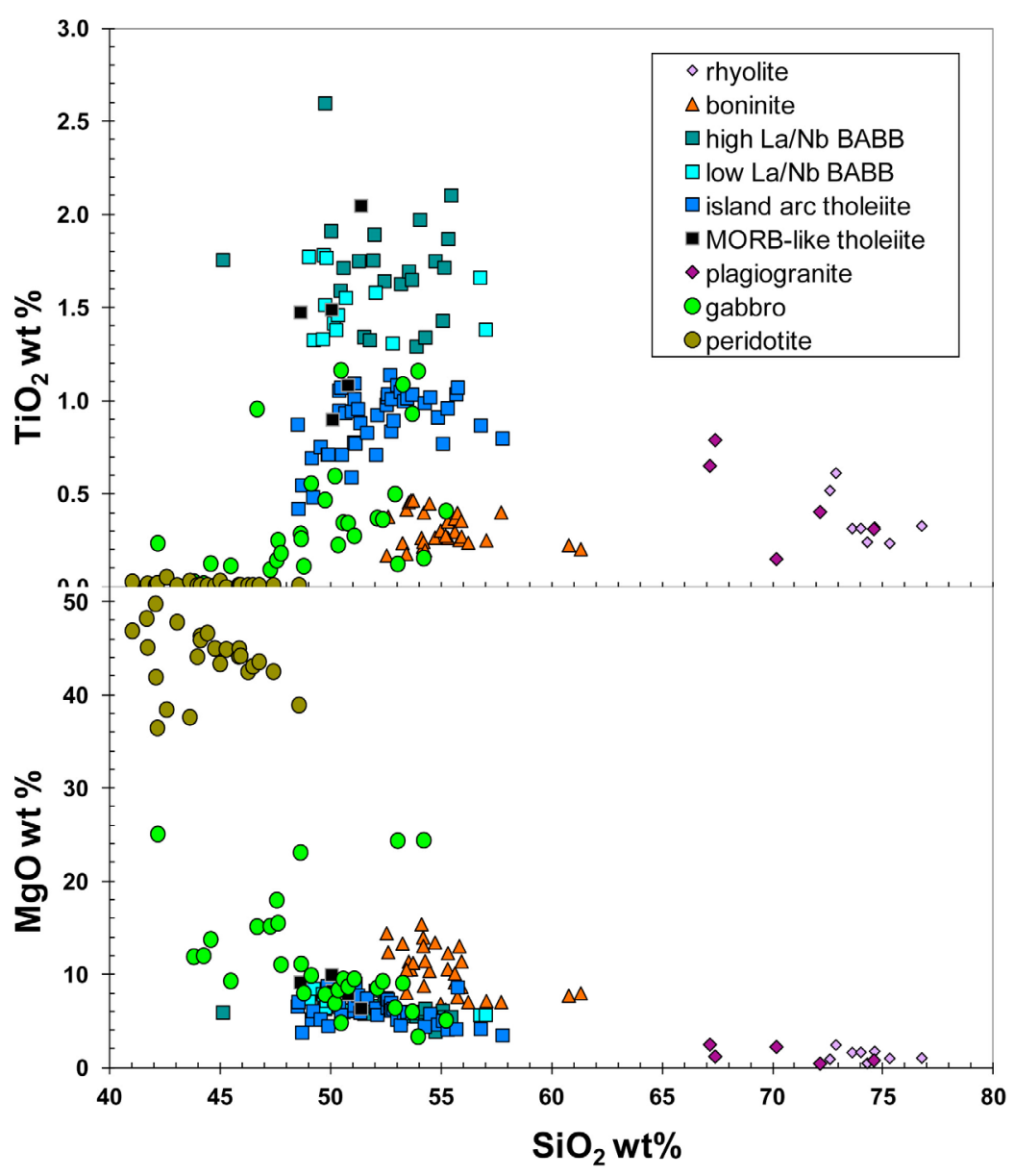

Figure 2. Major element chemistry of the Tonga fore arc samples showing geochemical groupings.

[12] There was a tendency for peridotites to be in the deepest $(8200-4100 \mathrm{~m})$ and for boninites to be located in the shallower dredges $(5800-3900 \mathrm{~m})$ and this is apparent in the whole rock geochemistry (Figure 3a). There is a significant overlap between the depth of these two rock types. However, the remainder of the rock types (the majority of the samples) occurred throughout the trench wall and showed no correlation with depth (Figure 3a). For example both the shallowest and the deepest dredge contained mostly rhyolites. Additionally no latitudinal trends (along the trench) are apparent in either the rock types or in the geochemistry (Figure $3 b$ ).

[13] Post emplacement seafloor alteration has strongly affected these rocks as indicated by a moderate correlation of $\mathrm{K}_{2} \mathrm{O}, \mathrm{Ba}, \mathrm{Rb}$ (Figure 4) with loss of ignition and a wide scatter of $\mathrm{Sr}$ values. The bivariate plots for the remainder of the elements, both again loss on ignition against relatively immobile elements, suggest that the values were not significantly affected by remobilisation. Systematic variation of $\mathrm{Mn}$ and $\mathrm{P}$ suggest that seafloor manganese crusts and phosphate enrichment have not influenced the data.

[14] The data plot in well defined chemical groupings on most bivariate plots and can be readily grouped into 8 separate suites:

[15] 1. Boninites have distinctive low $\mathrm{TiO}_{2}$, high $\mathrm{MgO}$ and $\mathrm{SiO}_{2}$ (Figure 2) and are similar to high $\mathrm{Ca}$ boninites from the northern Tonga area [Falloon and Crawford, 1991; Falloon et al., 2007, 2008]. Each dredge site has its own distinctive REE patterns (Figure 5) with a tendency for the most depleted heavy REE to be in the northern part of the fore arc. Boninite sample 114-3-1 in Table S2 was previously published in Falloon et al. [2007].

[16] 2. Plagiogranites have distinctive high $\mathrm{SiO}_{2}$ and low $\mathrm{TiO}_{2}$ and display negative $\mathrm{Eu}$ anomalies. The northernmost samples are strongly depleted in the heavy REE (Figure 5) and Y associated with enrichment in $\mathrm{La}$ and $\mathrm{Sr}$ relative to the more southern samples suggesting strong slab melt component to their petrogenesis (Figure 6). Plagiograntie sample 


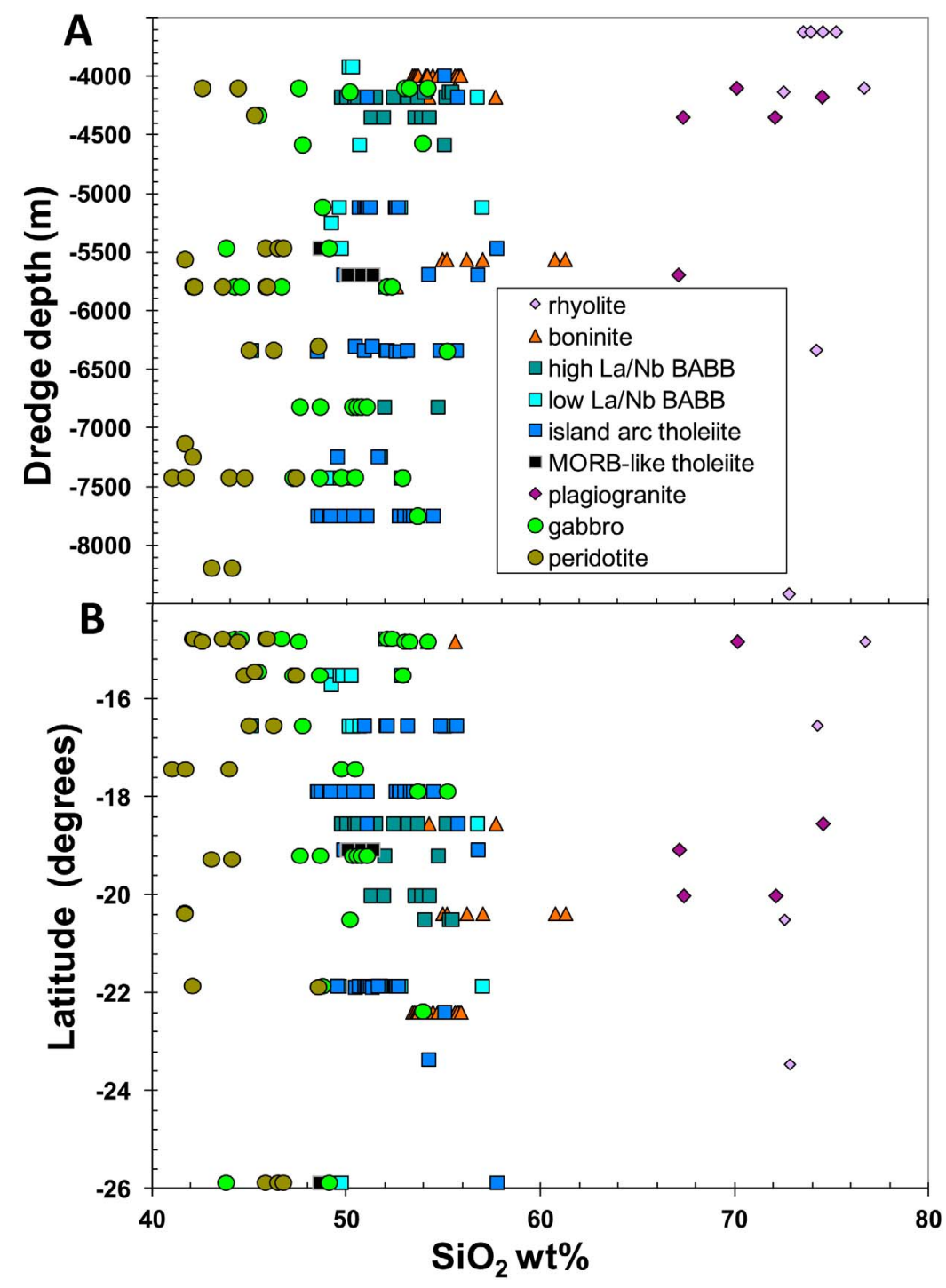

Figure 3. Bivariate plots showing that the relationship between rock type, silica contents and (a) dredge depth or (b) latitude.

113-2-12 in Table S2 was previously published in Falloon et al. [2008].

[17] 3. Rhyolites are similar to the southern plagiogranites in their major and trace element chemistry but do not show the slab melt characteristics of the northern plagiogranites.

[18] 4. Island arc tholeiites are one of the most prevalent rock type in the dredges. They are altered basalts and dolerites with low $\mathrm{TiO}_{2}(0.4-1.1 \mathrm{wt} \%)$ and moderate $\mathrm{MgO}$ (3.8-9.5 wt\%). They have prominent $\mathrm{Nb}$ anomalies on MORB normalized incompatible element diagrams (Figure 6) and slightly light REE depleted on chondrite normalized diagrams. Some have small $\mathrm{Eu}$ negative anomaly suggesting plagioclase fractionation (Figure 5). They are similar in their chemical character to island arc tholeiites (e.g., those of Ewart et al. [1998]).

[19] 5. A first group of BABB-type tholeiites [Sinton and Fryer, 1987] with low $\mathrm{La} / \mathrm{Nb}$ are similar to the arc tholeiites in major element chemistry but with higher $\mathrm{TiO}_{2}(0.9-2.2 \mathrm{wt} \%)$ and higher overall REE contents and slightly less light REE depleted in the chondrite normalized patterns (Figure 5).

[20] 6. A second group of BABB-type tholeiites have higher $\mathrm{La} / \mathrm{Nb}$ (Figure 7) and are more similar to MORB. They have a very shallow $\mathrm{Nb}$ anomaly in the MORB normalized incompatible element diagrams and are only slightly enriched in the light ion lithophile elements. 


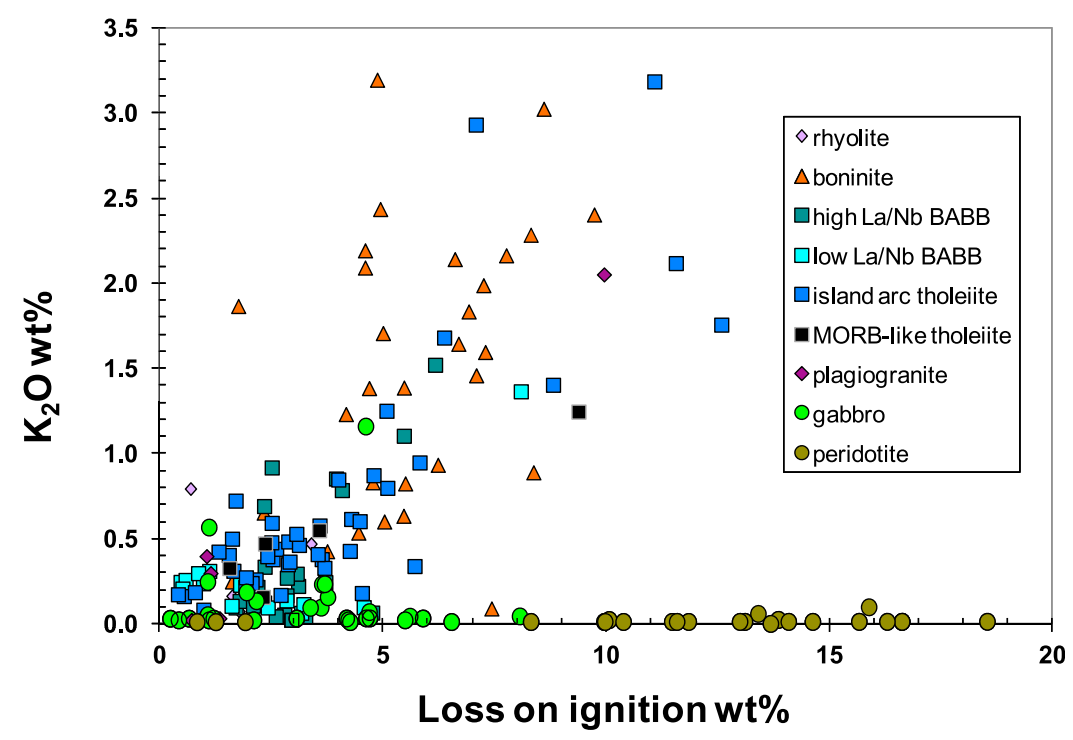

Figure 4. The strong relationship between loss on ignition and potassium contents suggests post crystallization remobilisation of the most mobile elements.

[21] 7. MORB-like basalts have higher $\mathrm{La} / \mathrm{Nb}$ than both of the BABB types described above at similar $\mathrm{TiO}_{2}$ and $\mathrm{MgO}$, have slightly flatter REE depleted patterns, and are transitional between E-MORB and N-MORB in their chondrite normalized patterns;

[22] 8. The majority of the gabbros analyzed probably belong to the arc tholeiite suite based on their trace element contents. Most have a small positive $\mathrm{Eu}$ anomaly suggesting a plagioclase cumulate origin (Figure 5). A small subset have slightly more enriched light REE patterns and slightly higher $\mathrm{TiO}_{2}$ contents and are probably the cumulate equivalent to the back-arc basin and MORB like tholeiite suites.

[23] 9. The majority of the peridotites analyzed are harzburgite with a small number of plagioclase harzburgite and lherzolites. They range between 35 and $50 \mathrm{wt} \% \mathrm{MgO}$ at $40-50 \% \mathrm{SiO}_{2}$ and $7-12 \mathrm{wt} \%$ $\mathrm{FeO}$. They display U shaped REE patterns which are typical of harzburgites from ophiolite and suprasubduction zone settings (Figure 5).

[24] Preliminary results for $\mathrm{Pb}, \mathrm{Sr}$ and $\mathrm{Nd}$ isotopes suggest a Pacific mantle source affinity for all of the samples. However, only a few samples were analyzed for $\mathrm{Pb}, \mathrm{Sr}$ and $\mathrm{Nd}$ and some problems were encountered with $\mathrm{Sr}$ isotopic values due to post eruption mobility and resetting.

\subsection{U-Pb Geochronology}

[25] The basalts, dolerites, boninites and plagiogranites range from 9 to $102 \mathrm{Ma}$ with clusters of ages between 9 and $12 \mathrm{Ma}, 28$ to $32 \mathrm{Ma}$ and 49 to
$52 \mathrm{Ma}$ (Table 1 and Figures 2 and 8). Most of the ages become younger northward suggesting successive domains with separate geological histories (as outlined on Figure 1). This is surprising as the geochemical data and rock types dredged show no latitudinal trends.

[26] A number of samples had no zircons or had very small and low $U$ zircons that could not be dated (see Table 2). Two of the samples had larger (10-20 micron) but low U zircons and the analyses on these crystals had very large uncertainties (20 $40 \%$ relative standard error $2 \sigma$ ) on the $\mathrm{U}$ and $\mathrm{Pb}$ ratios and the ages. All of the remaining samples had uni-modal zircon populations with no inheritance or complex age zoning (images of selected samples are presented in Figure S1). The rhyolitic rocks from ODP $841 \mathrm{~B}$ contained very few zircons and only three 40 micron crystals were recovered. Although the analysis of only three crystals is generally not recommended due to contamination issues, we are confident that there is no contamination as the ages are within the analytical uncertainty both of each other and of the previous ${ }^{40} \mathrm{Ar}-{ }^{39} \mathrm{Ar}$ dates and the rocks were processed and analyzed at a time when the laboratory was only processing Triassic and Proterozoic rocks making Eocene zircon contamination improbable.

[27] Approximately two thirds of the samples processed had no zircons. The felsic intrusive rocks contained numerous zircons as expected but surprisingly none of the rhyolitic rocks contained any zircons (Table 2). However, more than half the gabbros and one quarter of the dolerites contained 


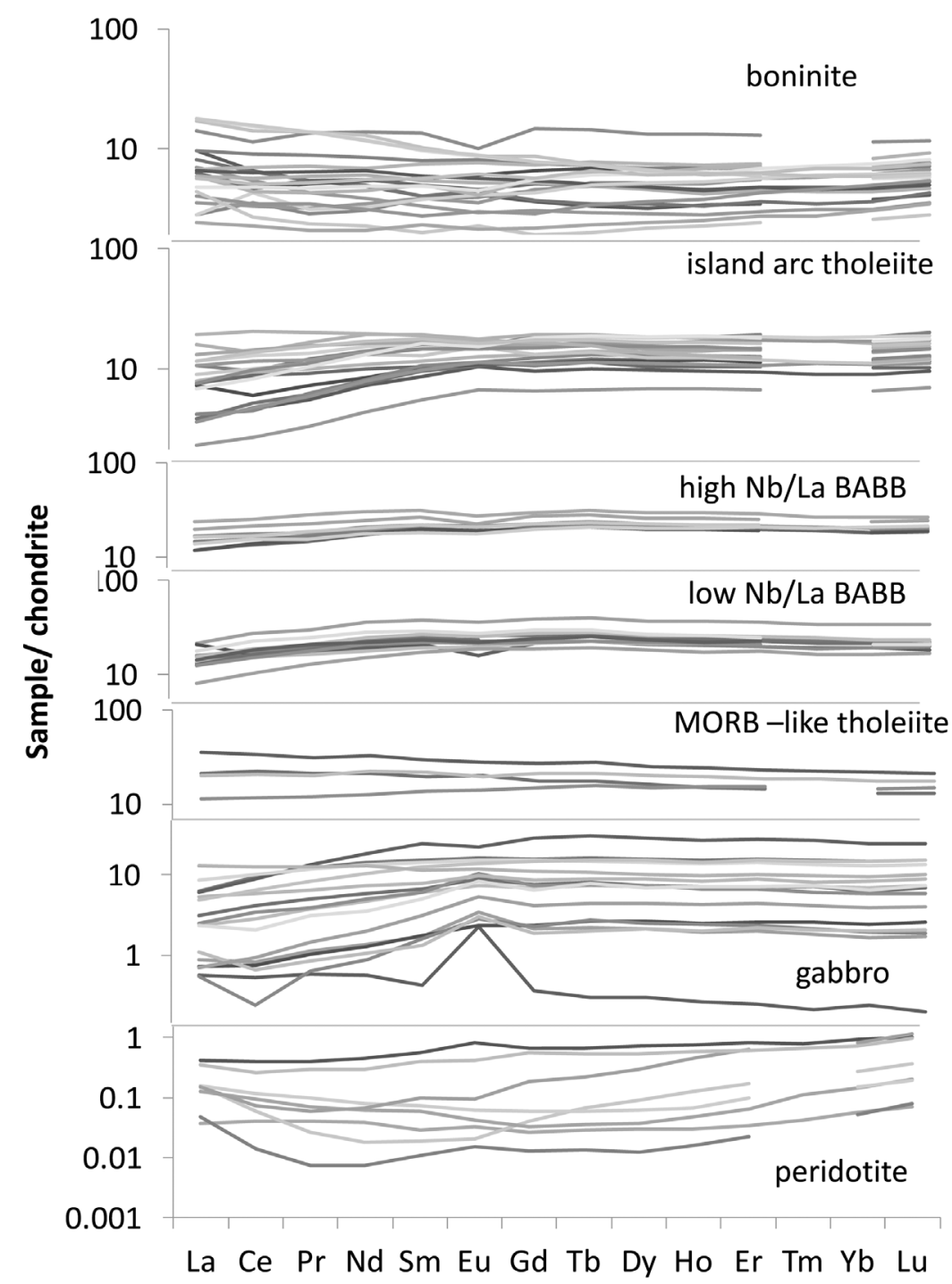

Figure 5. Chondrite normalized rare earth element plot for the major groups of rocks. Normalization values from Sun and McDonough [1989].

zircons large enough for dating (Table 1). The full results of the $\mathrm{U}-\mathrm{Pb}$ zircon dating together with concordia diagrams and results from the standards are presented in Table S1.

\section{4. ${ }^{40} \mathrm{Ar}^{-39} \mathrm{Ar}$ Geochronology}

[28] $\mathrm{The}^{40} \mathrm{Ar}^{-39} \mathrm{Ar}$ incremental heating data returned a similar age range compared to the $\mathrm{U}-\mathrm{Pb}$ data (Table 3 ). Although K mobility has certainly affected some of the samples (Figure 4), comparison with the $\mathrm{U}-\mathrm{Pb}$ data suggests that the ${ }^{40} \mathrm{Ar}-{ }^{39} \mathrm{Ar}$ data is on the whole reasonably representative of eruption ages of the fore arc rocks. For example the oldest ${ }^{40} \mathrm{Ar}-{ }^{39} \mathrm{Ar}$ age is in the same dredge as the oldest U-Pb date and both samples have similar geochemical characteristics lacking the prominent $\mathrm{Nb}$ anomaly on MORB normalized incompatible element diagrams present in most of the other fore arc rocks.

\section{Tectonic Implications}

\subsection{Mid-Cretaceous Dolerite}

[29] The Cretaceous basalt and dolerite encountered is much older than any other rock previously dated from this arc system. Unlike many of the other rocks this basalt and dolerite have typical MORB affinities with Pacific mantle $\mathrm{Pb}$ isotopic composition characteristised by high ${ }^{206} \mathrm{~Pb} /{ }^{204} \mathrm{~Pb}$ values These 


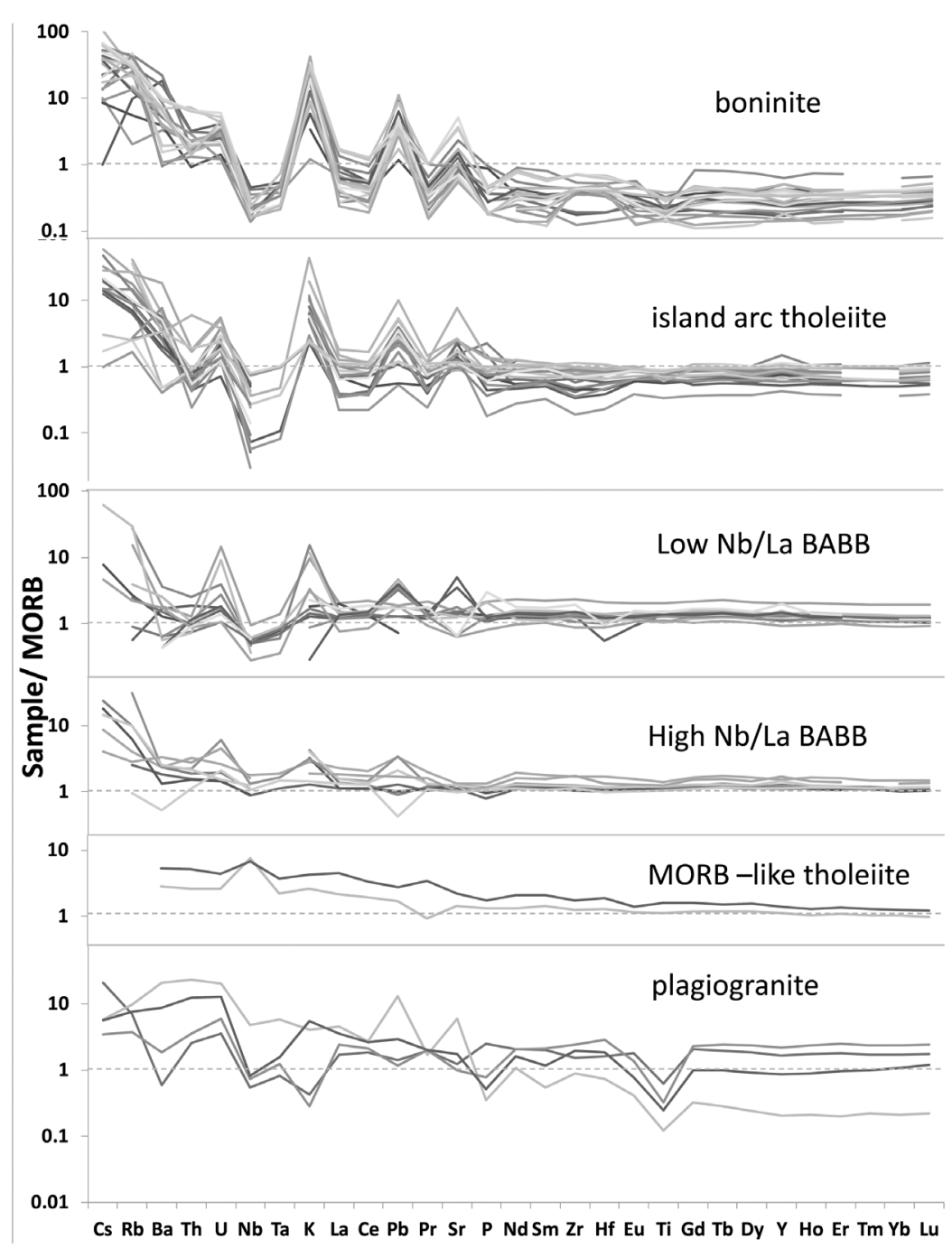

Figure 6. MORB normalized incompatible element plot for the major groups of rocks. Normalization values from Sun and McDonough [1989].

rocks could be emplaced in two possible ways: first they could be scraped of the Pacific plate and incorporated into the fore arc during subduction. This is supported by the fact that the age of one of the rocks is similar to that from the Pacific plate that is currently being subducted beneath Tonga (95$110 \mathrm{Ma}$ [Seton et al., 2009]); second, the basalt and dolerite could be a remnant of Cretaceous basement from the early history of the island arc system. Cretaceous basalts in the Marianas fore arc were initially thought to have been scraped off the Pacific plate and incorporated into the fore arc [Johnson et al., 1991]. However, recent geochemical data from Mesozoic basalts from the Bonin fore arc [Ishizuka et al., 2011] have shown that these rocks have an isotopic composition unlike that from the Pacific plate, suggesting they were part of the subductionrelated Cretaceous oceanic crust on the Philippine
Sea Plate [Hickey-Vargas, 2005; Hickey-Vargas et al., 2008]. Like the basalts from the Bonin and Mariana systems the Mesozoic basalt and dolerite from this study were recovered from between 5 and $6 \mathrm{~km}$ of water depth in the middle part of the trench slope but unlike the basalts from the Bonin system the isotopic characteristics do not help to discriminate between different genetic scenarios.

[30] Both the Cretaceous rocks from this study and those from the Bonin fore arc were recovered from dredges which contain younger basalts. The younger basalts in Tonga dredge 100 are geochemically distinct (Figures 6 and 7) with depleted arc tholeiite or backarc basin basalt type geochemistry contrasting with the Creatceous rocks from the same dredge site. These basalts have a recoil-affected ${ }^{40} \mathrm{Ar}^{39} \mathrm{Ar}$ (total fusion) age of 29.9 Ma suggesting that they 


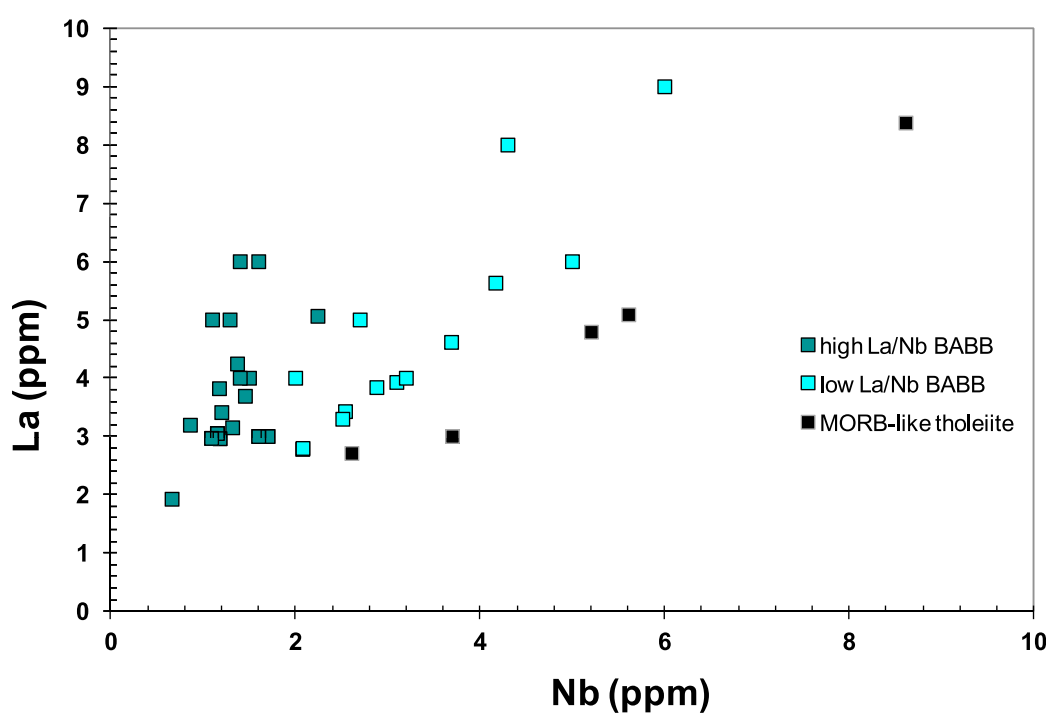

Figure 7. Plot of La and $\mathrm{Nb}$ showing the distinction between the BABB tholeiites and the MORB like tholeiites.

are part of the same 28-35 Ma ocean crust that was sampled at dredge site 102 and 105 further to the north (Figure 1). The Cretaceous basalts have geochemical characteristics that are within the range of both Cretaceous crust obducted onto New Caledonia (Poya Terrane [Nicholson et al., 2000a]) and New Zealand (Northland [Nicholson et al., 2000b]) but also the nearby Pacific crust [Castillo et al., 2009] making it difficult to ascertain their provenance.

\subsection{Initiation of the Tonga-Kermadec and Bonin-Mariana Systems}

[31] Studies on the initiation of the west Pacific island arc system have been numerous and based on three sources of primary information: (1) geophysical modeling which suggests that the easiest place to initiate an island arc in an oceanic setting is at transform faults that juxtapose old and young crust [Casey and Dewey, 1984; Toth and Gurnis, 1998; Hall et al., 2003; Stern, 2004]; (2) petrological information that indicates widespread hydrous shallow mantle melting (boninite,[Crawford et al., 1989; Stern and Bloomer, 1992, Hawkins, 1994]) or slab melting (adakite [Cluzel et al., 2006, 2012]) shortly after subduction initiation; (3) studies of ophiolites worldwide, particularly Oman and Cyprus, suggest that the beginning of subduction is accompanied by rapid spreading characterized by tholeiite and/or boninite [e.g., Ishikawa et al., 2002]; and (4) new

Table 1. Summary of U-Pb Zircon Data

\begin{tabular}{|c|c|c|c|c|c|c|c|c|}
\hline $\begin{array}{l}\text { Sample } \\
\text { Number }\end{array}$ & $\begin{array}{l}\text { Rock } \\
\text { Type }\end{array}$ & $\begin{array}{l}\text { Age } \\
\text { (Ma) }\end{array}$ & $2 \sigma$ Error & $\begin{array}{l}\text { Number } \\
\text { of Zircons }\end{array}$ & $\begin{array}{l}\text { Laser Spot } \\
\text { Size }(\mu \mathrm{m})\end{array}$ & Lat & Long & $\begin{array}{l}\text { Depth } \\
\text { (m) }\end{array}$ \\
\hline $100-1-40$ & dolerite & 102.2 & 4.5 & 9 & 10 & -19.060 & -173.042 & -6020 \\
\hline $96-1-2$ & gabbro & 51.2 & 0.8 & 12 & 30 & -20.000 & -173.433 & -4880 \\
\hline $96-1-15$ & gabbro & 49.8 & 1.1 & 12 & 30 & -20.000 & -173.433 & -4880 \\
\hline ODP841b & breccia & 42.5 & 2.7 & 3 & 30 & -23.346 & -175.298 & -5007 \\
\hline $102-4-1$ & granite & 35.9 & 1.1 & 12 & 30 & -18.270 & -172.830 & -4575 \\
\hline $105-1-9$ & granite & 28.2 & 1.8 & 12 & 30 & -17.869 & -172.607 & -6608 \\
\hline $108-3-10$ & dolerite & 12.1 & 6.4 & 4 & 10 & -16.527 & -172.458 & -4828 \\
\hline \multicolumn{9}{|c|}{ Very Low Precision } \\
\hline $106-1-40$ & dolerite & 11.7 & 8.2 & 2 & 10 & -17.417 & -172.409 & -7723 \\
\hline $114-1-38$ & gabbro & 16 & 28 & 1 & 10 & -14.750 & -173.358 & -6180 \\
\hline $94-2-1$ & dolerite & \multicolumn{2}{|c|}{$\begin{array}{l}\text { too small } \\
\text { to be useful }\end{array}$} & 1 & 10 & -20.489 & -173.512 & -4589 \\
\hline \multicolumn{9}{|c|}{ Previously Published } \\
\hline $107-1-7$ & dolerite & 12.2 & 0.3 & 14 & $10 \& 30$ & -16.523 & -172.300 & -6590 \\
\hline $111-4-6$ & gabbro & 10.1 & 1.6 & 3 & 10 & -15.500 & -172.338 & -7691 \\
\hline $113-2-12$ & gabbro & 2.7 & 0.2 & 12 & 30 & -14.811 & -173.402 & -4300 \\
\hline
\end{tabular}




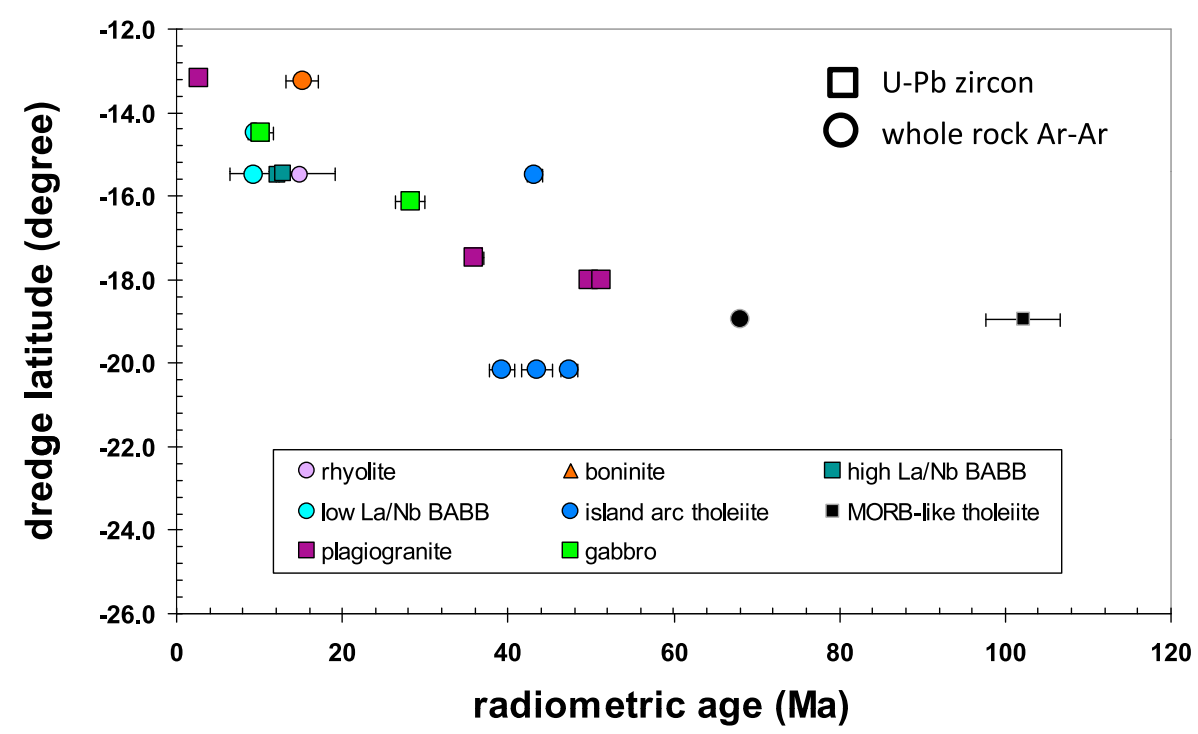

Figure 8. Plot of the ${ }^{40} \mathrm{Ar}-{ }^{39} \mathrm{Ar}$ data (circles) and U-Pb data (squares) for the major rock types dredged showing that the rocks tend to become younger to the north. Uncertainties are 2 sigma for U-Pb but one sigma for ${ }^{40} \mathrm{Ar}-{ }^{39} \mathrm{Ar}$.

observations from the Bonin and Mariana fore arc that suggest the early arc-related sightly depleted tholeiitic basalts occur beneath the boninitic rocks and are older than the boninite by 2 to $8 \mathrm{Ma}$ [Reagan et al., 2010, Ishizuka et al., 2011].

[32] The first three sources of information are relatively consistent with each other suggesting that during the earliest histories of these arcs hot shallow hydrous mantle or slab melts are emplaced in the base of supra subduction zone ophiolites or erupted at the surface. The new observations on the fore arc basalts of the Bonin and Mariana fore arc are more difficult to explain. The chemistry of these fore arc basalts is very similar to modern basalts erupted in back arc basins. They strongly resemble mid ocean ridge basalts with an additional enrichment in large ion lithophile elements and depletion in some of the high field strength elements. These basalts are the products of decompression melting of the mantle [Ishizuka et al., 2011, Todd et al., 2012] due to upwelling of the mantle that has been partially contaminated by small amounts of subduction related fluids.

[33] Two models have been used to explain the presence of these basalts in the fore arc: (1) older models [e.g., DeBari et al., 1999] argued that these fore arc basalts were trapped from the pre-existing oldest parts of the West Philippine basin oceanic plate; and (2) Reagan et al. [2010] and Whattam and Stern [2011] argued that these basalts were created during the initial stages of a west-dipping subduction system on the grounds that transitional magmas between boninite and fore arc basalts exist in the Mariana fore arc and in many ophiolites where boninites are present. They hypothesize that these basalts were generated as mantle upwelled into a gap created between the two plates during the initial stages of subduction initiation.

[34] In the Tonga system we have evidence [Cluzel et al., 2006, 2012] that the west-dipping Tonga subduction zone was preceded by around 7 million years by the east-dipping Loyalty-Three Kings intraoceanic subduction zone (58-56 Ma) and probably an analogous system with similar age and geometry in

Table 2. List of Samples With No Zircons

\begin{tabular}{ccc}
\hline Sample Number & Rock Type & Method \\
\hline $81-1-3$ & Rhyolite & mineral separates \\
$83-3-1$ & Rhyolite & mineral separates \\
$94-2-5$ & Rhyolite & mineral separates \\
$107-1-10$ & Rhyolite & mineral separates \\
$112-1-2$ & Gabbro & mineral separates \\
$113-1-32$ & Rhyolite & mineral separates \\
$118-2-8$ & Rhyolite & mineral separates \\
$118-2-5$ & Rhyolite & mineral separates \\
$82-3-2$ & Gabbro & automated SEM \\
$87-1-2$ & Gabbro & automated SEM \\
$96-2-6$ & Dolerite & automated SEM \\
$99-2-8$ & Dolerite & automated SEM \\
$100-1-39$ & Dolerite & automated SEM \\
$102-1-17$ & Dolerite & automated SEM \\
$104-1-57$ & Dolerite & automated SEM \\
$106-3-7$ & Dolerite & automated SEM \\
$110-1-1$ & Dolerite & automated SEM \\
$111-1-18$ & Dolerite & automated SEM \\
$112-1-2$ & Gabbro & automated SEM \\
\hline
\end{tabular}


Table 3. Age Determinations From ${ }^{40} \mathrm{Ar}-{ }^{39} \mathrm{Ar}$ Incremental Heating Experiments

\begin{tabular}{lcccc}
\hline $\begin{array}{c}\text { Sample } \\
\text { Number }\end{array}$ & Chemical Group & $\begin{array}{c}\text { Total Fusion } \\
\text { Age (Ma) }\end{array}$ & $\begin{array}{c}\text { Plateau Age } \\
( \pm 1 \mathrm{~s}, \text { Ma) }\end{array}$ & $\begin{array}{c}\%^{39} \text { Ar in } \\
\text { Plateau }\end{array}$ \\
\hline $90-1-8$ & BABB-type Tholeiite (high Nb/La) & 49.5 & $47.36 \pm 0.97$ & 88.9 \\
$90-1-40$ & BABB-type Tholeiite (low Nb/La) & 42.1 & $39.25 \pm 1.48$ & 87.1 \\
$90-1-13$ & Island arc-type Tholeiite & 51.2 & $43.56 \pm 1.84$ & 59.9 \\
$100-1-8$ & BABB-type Tholeiite (low Nb/La) & 68.0 & (no plateau, recoil release) \\
$100-1-1$ & (no plateau, recoil release) & $43.24 \pm 0.99$ & 100 \\
$107-1-4$ & Island arc-type Tholeiite & 29.9 & $14.86 \pm 0.23$ & 99.4 \\
$107-1-10$ & Rhyolite & 42.9 & $9.33 \pm 1.52$ & 100 \\
$109-2-5$ & BABB-type Tholeiite (low Nb/La) & 9.2 & $9.53 \pm 2.18$ & 54.8 \\
$111-1-8$ & BABB-type Tholeiite (low Nb/La) & 7.1 & $15.21 \pm 1.94$ & 100 \\
$114-3-1$ & Boninite & 15.6 & & \\
\hline
\end{tabular}

a Proportion of the total gas released that is included in the plateau age. Ages calculated relative to standard FCT-3 biotite (28.04 Ma).

the Papua New Guinea region [Whattam, 2009]. When the Tonga arc is reconstructed to its $52-48 \mathrm{Ma}$ position by removing the Lau and South Fiji Basins, it moves into a back arc environment behind the already active Loyalty-Three Kings arc. This tectonic scenario is shown in reconstructions by Hall [2002] and Crawford et al. [2003] and raises the possibility that the 52-48 Ma fore arc basalts could have formed during back arc spreading behind the eastdipping Three King-Loyalty arc. This back arc basin later becomes the fore arc of the new subduction system when subduction reverses and begins to occur above a west-dipping slab. The model of Hall [2002] shows that an analogous situation probably existed in the Bonin and Mariana areas between 55 and $49 \mathrm{Ma}$, with back arc spreading occurring behind the east-dipping slab subducted beneath the Philippine Sea Plate. It is therefore possible that during this period a large amount of back arc crust was created behind the east dipping subduction systems to form the bulk of the crust that later goes on to form a large portion of the back arc of the Tonga, Bonin and Mariana fore arc. Although this possibility is discounted by some previous studies [Reagan et al., 2010; Whattam and Stern, 2011], it remains a viable alternative to the fore arc basalt model for both areas.

[35] We argue that the evidence from ophiolites and the presence of transitional magmas between the fore arc basalts and the boninites do not favor either the "pre-existing back arc basin" or the "fore arc basalt" hypotheses. In an area where subduction initiates at or near mid ocean ridges, such as that favored by Hall et al. [2003], mantle upwelling is already occurring prior to the initiation and the timing between back arc basin spreading and fore arc boninitic magmatism could be very short or both may occur at the same time within a few kilometers. Another complication with some of the boninite and ophiolite data is that boninites do not only form during subduction initiation but also where back arc spreading centers propagate into the fore arc region, such as the situation in the northern Lau Basin [Falloon et al., 2007, 2008] and southern termination of the New Hebrides Arc and the North Fiji Basin [Monzier et al., 1993; Danyushevsky et al., 2005]. Some of the boninites that occur in ophiolites probably originated in these types of tectonic settings [e.g., Meffre et al., 1996]. In these ophiolites applying the "subduction rule" of Whattam and Stern [2011], stipulating that mid ocean ridge-type basaltic magmatism must be present prior to a boninitic event in supra-subduction zone ophiolites could lead to considerable confusion. At present, age constraints on boninites in the Tonga region are restricted to 0 to $2.7 \mathrm{Ma}$ in the northern Lau Basin [Falloon et al., 2008], 15.2 Ma at dredge 114 (this study) and late Eocene (minimum) from Fiji [Todd et al., 2012] so it is likely that some of the boninites from the Tonga fore arc will have been erupted during the early history of the arc, however, they also occurred at various times in the more recent the history of the arc, whenever spreading has occurred near the trench.

[36] The other concern with the fore arc basalt model is that it is difficult to see from a geometric and petrogenetic point of view how magmas formed by decompression melting of relatively deep mantle, only slightly contaminated by supra-subduction zone fluids, could be erupted in a setting such as that present at the beginning of subduction. In this model a small amount of mantle begins to interact with the hydrated edge and uppermost part of an old hydrated slab. In such a situation a rapid release of water causing shallow hydrous melting could be expected (Figure 9). However, the fore arc basalt models suggest that magmas derived from mantle upwelling are only slightly contaminated by hydrous fluids. The 


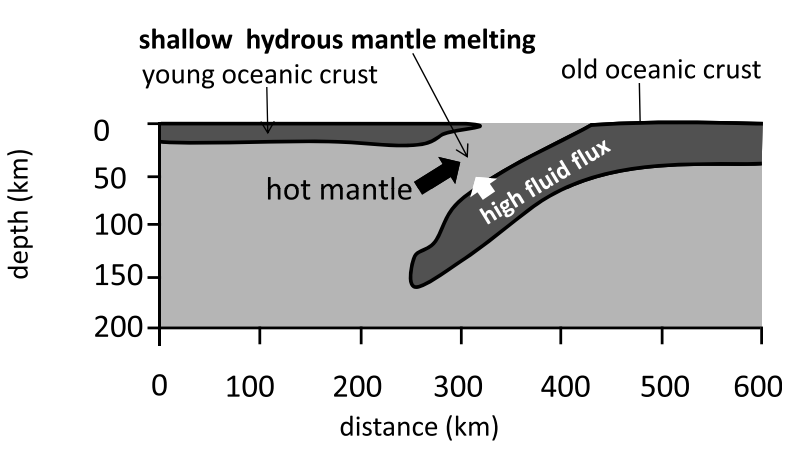

Figure 9. Mantle model of Hall et al. [2003] at 6.8 million years after the beginning of subduction showing that shallow hydrous mantle melting should dominate during the initiation of subduction where the overriding plate is $40 \mathrm{Ma}$ younger than the downgoing plate.

geometry of all the reconstructions at present, including Reagan et al. [2010], Whattam and Stern [2011] and Todd et al. [2012] predict a relatively small, shallow, hot, supra-subduction zone mantle wedge coming in close contact with a large amount of old hydrated slab. From a petrogenetic point of view this is a recipe for boninite not back arc basin type basalts. Although the fore arc basalt model could explain the creation of a large amount of 49$52 \mathrm{Ma}$ crust in the fore arc region from a tectonic point of view, a thorough evaluation of the geophysical and petrological plausibility for this scenario must be undertaken.

[37] The data set from this and other studies from the Tonga arc and the Hunter zone at the termination of the South Fiji Basin [e.g., Falloon et al., 2008; Cooper et al., 2010] show that the fore arc continues to grow well after the arc initiation, with continued basaltic and boninitic magmatism occurring during episodes of arc extension at the start of back arc spreading and when already established spreading centers cross into the fore arc areas. The data from the SW Pacific, not just in the active systems but also in ancient ophiolites [Crawford et al., 1989; Meffre et al., 1996], show that boninites can either follow or precede back arc or even MORB-like tholeiites and there is no regular chemostratigraphic progression from less to more depleted through time that can be generally applied to all ophiolites.

\subsection{Cenozoic Tectonic Evolution of the SW Pacific}

[38] The tectonic evolution of the SW Pacific has a long history which involves repeated cycles of continental and island arc volcanism, collision, ophiolite emplacement and rifting [Crawford et al., 2003]. The results from this study relate to the Cenozoic part of this history, although the presence or absence of a Late Cretaceous arc remains relevant to the starting configuration. The presence of a Late Cretaceous arc has been postulated on the basis of both petrological and geochemical [Cluzel et al., 2010; Crawford et al., 2003; Whattam et al., 2008] and geophysical grounds [Schellart et al., 2006, Rey and Muller, 2010]. Detailed work on the sedimentary rocks in New Caledonia [Cluzel et al., 2011] indicates the presence of an arc between 130 and $95 \mathrm{Ma}$ age range. However, no Cretaceous arc volcanic rocks have yet been recovered outboard of New Caledonia, the Norfolk Ridge and New Zealand. This is surprising as the complex topography present throughout that area exposes rocks from various parts of the crust. Data from dredged rocks have been gradually accumulating and the geology of the islands is now becoming relatively well documented. If Cretaceous arc rocks were present we would expect to have sampled them by now. The Cretaceous dolerite and basalt recovered by this study are ocean basin rocks and can only be distantly related to a Cretaceous arc. It is therefore probable that the Cretaceous arc has rolled back outside the Vanuatu-Fiji-TongaKermadec area. If we assume that this arc was in part driving the extension in the Coral Sea, the New Caledonia Basin and the Cretaceous basin east of New Caledonia (sometimes referred to as the South Loyalty Basin) then the spreading direction suggests it is probably buried somewhere under the Solomon Islands or near the extinct Vitiaz Trench rather than further south in the Tonga area.

[39] The Paleocene (57 Ma) beginning of the subduction along the Loyalty-Three Kings arc and its extension to the Northland ophiolite to the south and Papuan ultramafic belt to the north are now well established and documented. The data presented in this paper of 49-51 Ma formation of the Tonga fore arc crust strongly favors models which show the Tonga arc beginning after the Loyalty-Three Kings arc [e.g., Hall, 2002; Crawford et al., 2003; Cluzel et al., 2006] rather than those which show that the arc existed in the present orientation since the Cretaceous [e.g., Schellart et al., 2006; Whattam et al., 2008]. In a model where subduction has occurred from the Cretaceous to the present we would expect the fore arc of the Tonga arc to be mostly built on Cretaceous arc crust rather than the dominant 51-49 Ma island arc tholeiites documented here.

[40] In the model of Crawford et al. [2003] (Figure 10), the Tonga-Kermadec arc begins diachronously from north to south following the demise of the LoyaltyThree Kings arc. Hall [2002] shows the Tonga- 

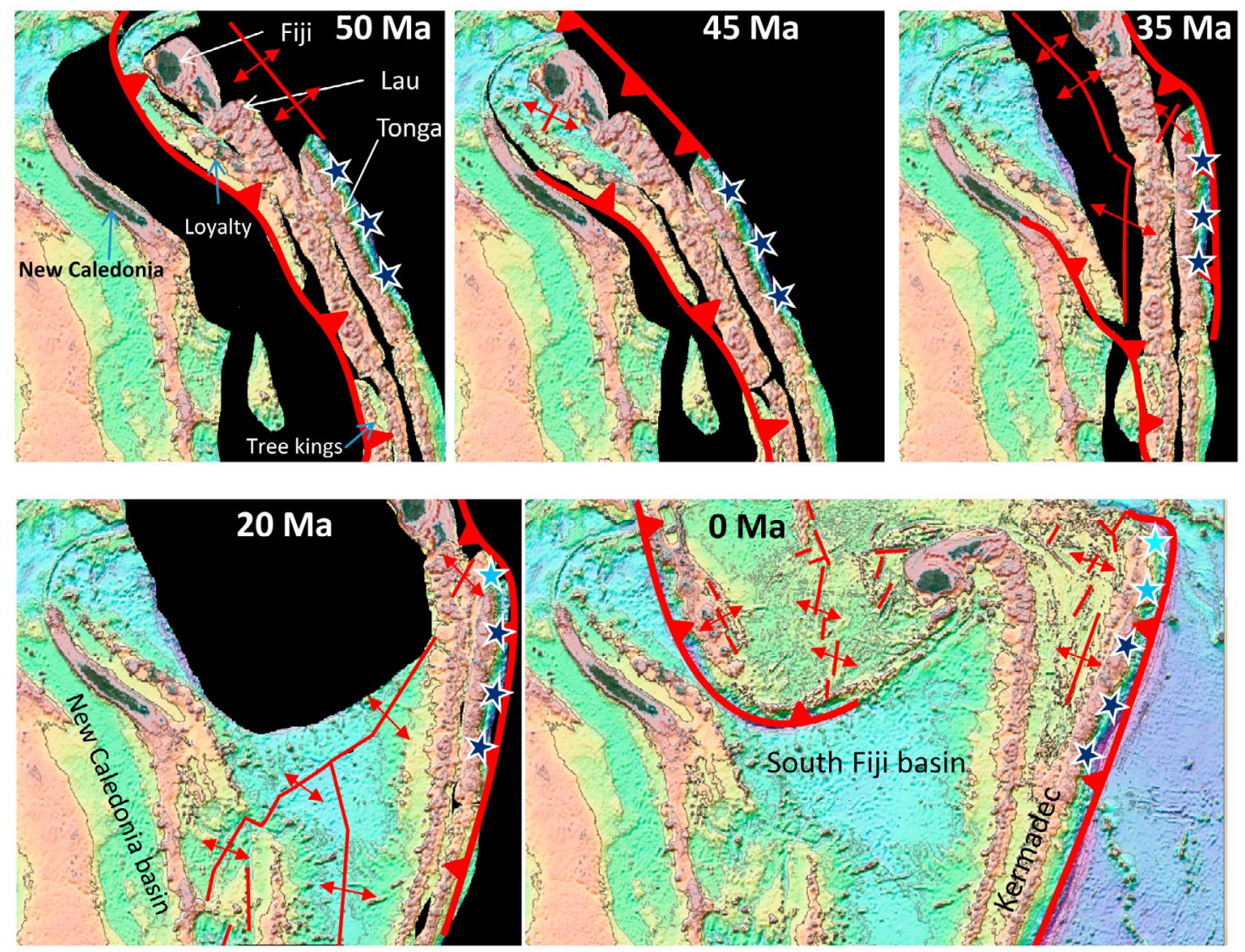

Figure 10. Tectonic evolution of the SW Pacific showing the location of the dredge sites (stars) through time. The model best supported by the data is similar to that outlined by Crawford et al. [2003] and Mortimer et al. [2007]. The blue stars shows the location of selected samples through time with dark stars representative of the oldest and light blue stars the youngest samples. Black areas show areas where the oceanic crust has been subducted or overthrust.

Kermadec arc beginning synchronously at $45 \mathrm{Ma}$. We would argue that lack of 45-33 Ma back arc crust in the southern part of the South Fiji Basin or the lack of Eocene rocks in the dredges from the Three Kings and edge of the South Fiji Basin favors the diachronous reversal model. However, to constrain this further, data from the Kermadec fore arc and from the southern part of the Lau Ridge are required. One of the interesting results of this study are the young ages from many of the dolerites and basalts recovered. This is unlikely to be due to analytical artifacts as both the U-Pb and ${ }^{40} \mathrm{Ar}-{ }^{39} \mathrm{Ar}$ system show ages for dolerite and basalts as young as 9 or $10 \mathrm{Ma}$ erupted in the fore arc. U-Pb ages cluster around 28-32 Ma for plagiogranites and 1012 Ma for dolerites. The 28-32 Ma dates could relate to the initiation of back-arc rifting in the South Fiji Basin [see Mortimer et al., 2007; Herzer et al., 2011]. The 9-12 Ma dates probably relate to the beginning of spreading in the North Fiji Basin and the northern Lau Basin following Vitiaz arc reversal and the inception of the New Hebrides arc. The 9$12 \mathrm{Ma}$ dates from this study are from the northern dredges indicating that a significant part of the fore arc in this area must have formed at that time. The model of Crawford et al. [2003] agrees well with the existing geochemical and age data from the southwest Pacific as a whole. However, recent geophysical modeling [Schellart and Spakman, 2012] that tested the reconstruction of Mortimer et al. [2007] (a model similar in geometry to Crawford et al. [2003]) found small discrepancies between the observed modern mantle seismic velocity field and that predicted by the geometry of the models.

\section{Conclusions}

[41] Tongan fore arc basalts, dolerites and boninites were created during at least four separate periods indicating a complex genesis for fore arc crust. The oldest rock sampled is a $100 \mathrm{Ma}$ Cretaceous mid 
ocean ridge like basalt which could have originated on either the Australian or the Pacific plate. The bulk of the fore arc south of the $18^{\circ} \mathrm{S}$ parallel was created between 52 and $39 \mathrm{Ma}$, starting with 51$49 \mathrm{Ma}$ basalts and dolerite with similar chemical characteristics to modern back arc basin basalts, and finishing with 43-39 Ma dolerites and rhyolites. Two possible tectonic scenarios could account for the 52-49 Ma basalts. They could have been generated in the fore arc during subduction initiation or, more likely, they formed in a back arc setting behind the Three Kings Loyalty arc and were then incorporated into the fore arc during arc reversal in the Late Eocene (Figure 10). Immediately to the north of the Eocene fore arc 28-32 Ma plagiogranites were dredged. These were probably formed during the initial stages of the formation of the South Fiji Basin, north of $17^{\circ} \mathrm{S}$. Most of the dolerites and boninites were formed in the 9-12 Ma period during the initiation of rifting in the northern Lau and North Fiji Basin immediately after the reversal of the Vitiaz arc.

[42] Fore arc crust in the Tonga area was created episodically during the emplacement of basalts, rhyolites, plagiogranites and boninites associated with major extensional events throughout the history of the arc. These findings reinforce those of previous studies that indicate that basalts and boninites in ophiolites are not necessarily created during the initiation of subduction, but can form whenever the arc crust undergoes extension. These conclusions suggest that applying a Marianas fore arc model to ophiolites worldwide will result in an oversimplification of the true diversity and complexity that is typically present in modern and ancient arc-related ocean crust formation.

\section{Acknowledgments}

[43] We wish to thank all the scientists, officers, and crew who participated on the 1996 R/V Melville voyage, Boomerang Leg 8. Many thanks to Karsten Goemann and Maya Kamenetsky at the University of Tasmania Central Science Laboratory, where the SEM-MLA zircon search technique was perfected. Sarah Gilbert, Chris Hollitt, and Leonid Danyushevsky provided superb guidance in all things LA-ICP-MS. We thank Phil Robinson and Katie McGoldrick for their help with geochemical analyses. This research was supported by the Australian Research Council and by NSF grants OCE-9521023 and OCE9521039. We also thank two anonymous reviewers and editor James Tyburczy for their helpful comments.

\section{References}

Banerjee, N. R., and K. M. Gillis (2001), Hydrothermal alteration in a modern suprasubduction zone: The Tonga fore arc crust, J. Geophys. Res., 106, 21,737-21,750, doi:10.1029/2001JB000335.

Banerjee, N. R., K. M. Gillis, and K. Muehlenbachs (2000), Discovery of epidosites in a modern oceanic setting, the Tonga fore arc, Geology, 28, 151-154, doi:10.1130/00917613(2000)28<151:DOEIAM $>2.0 . C O ; 2$.

Becker, T. W., C. P. Conrad, B. Buffet, and R. D. Muller (2009), Past and present seafloor age distributions and the temporal evolution of plate tectonic heat transport, Earth Planet. Sci. Lett., 278, 233-242, doi:10.1016/j.epsl.2008. 12.007.

Black, L. P., S. L. Kamo, C. M. Allen, J. N. Aleinikoff, D. W. Davis, R. J. Korsch, and C. Foudoulis (2003), TEMORA 1: A new zircon standard for Phanerozoic U-Pb geochronology, Chem. Geol., 200, 155-170, doi:10.1016/S0009-2541 (03)00165-7.

Bloomer, S. H., and D. J. Wright (1996), Summary of Site Survey Cruise Results, Boomerang Leg 08, in Support of Proposal 451, Ocean Drilling in the Tonga Fore arc: Subduction Geodynamics, Arc Evolution, and Deformation Processes at a Non-Accretionary Convergent Margin, Ocean Drillling Proram Site Survey Cruise Report, Oreg. State Univ., Corvallis.

Bloomer, S. H., et al. (1996), Geology of the Tonga fore arc: A suprasubduction zone ophiolite, Eos Trans. AGU, 77, 325.

Bloomer, S. H., T. J. Falloon, H. Petcovic, R. L. Neilsen, and R. A. Duncan (1998), Petrology and geochemistry of volcanic and plutonic rocks from the Tonga fore arc, southwest Pacific, Eos Trans. AGU, 79, 188.

Casey, J. F., and J. F. Dewey (1984), Initiation of subduction zones along transform and accreting plate boundaries, triple-junction evolution, and fore arc spreading centres; implications for ophiolitic geology and obduction, in Ophiolites and Oceanic lithosphere, edited by J. W. Gass, S. J. Lippard, and A. W. Shelton, Geol. Soc. Spec. Publ., 13, pp. 269-290.

Castillo, P. R., P. F. Lonsdale, C. L. Moran, and J. W. Hawkins (2009), Geochemistry of mid-Cretaceous Pacific crust being subducted along the Tonga-Kermadec Trench: Implications for the generation of arc lavas, Lithos, 112, 87-102, doi:10.1016/j.lithos.2009.03.041.

Clift, P. D., C. J. MacLeod, D. R. Tappin, D. J. Wright, and S. H. Bloomer (1998), Tectonic controls on sedimentation and diagenesis in the Tonga Trench and fore arc, southwest Pacific, Geol. Soc. Am. Bull., 110, 483-496, doi:10.1130/ 0016-7606(1998)110<0483:TCOSAD > 2.3.CO;2.

Cluzel, D., S. Meffre, P. Maurizot, and A. J. Crawford (2006), Earliest Eocene (53 Ma) convergence in the Southwest Pacific: Evidence from pre-obduction dikes in the ophiolite of New Caledonia, Terra Nova, 18, 395-402, doi:10.1111/ j.1365-3121.2006.00704.x.

Cluzel, D., C. J. Adams, S. Meffre, H. Campbell, and P. Maurizot (2010), Discovery of early cretaceous rocks in New Caledonia: New Geochemical and U-Pb zircon age constraints on the transition from subduction to marginal breakup in the Southwest Pacific, J. Geol., 118, 381-397, doi:10.1086/652779.

Cluzel, D., C. J. Adams, P. Maurizot, and S. Meffre (2011), Detrital zircon records of Late Cretaceous syn-rift sedimentary sequences of New Caledonia: An Australian provenance questioned, Tectonophysics, 501, 17-27, doi:10.1016/j.tecto.2011. 01.007 . 
Cluzel, D., F. Jourdain, S. Meffre, P. Maurizot, and S. Lesimple (2012), The metamorphic sole of New Caledonia ophiolite: ${ }^{40} \mathrm{Ar} /{ }^{\beta 9} \mathrm{Ar}, \mathrm{U}-\mathrm{Pb}$, and geochemical evidence for subduction inception at a spreading ridge, Tectonics, 31, TC3016, doi:10.1029/2011TC003085.

Cooper, L. B., T. Plank, R. J. Arculus, E. H. Hauri, P. S. Hall, and S. W. Parman (2010), High-Ca boninites from the active Tonga Arc, J. Geophys. Res., 115, B10206, doi:10.1029/ 2009JB006367.

Crawford, A. J., T. J. Falloon, and D. H. Green (1989), Classification, petrogenesis and tectonics setting of boninites, in Boninites, edited by A. J. Crawford, pp. 1-49, Unwin Hyman, London.

Crawford, A. J., S. Meffre, and P. Symonds (2003), 120 to $0 \mathrm{Ma}$ tectonic evolution of the southwest Pacific and analogous geological evolution of the 600 to $220 \mathrm{Ma}$ Tasman Fold Belt System, in Evolution and Dynamics of the Australian Plate, edited by R. R. Hillis and R. D. Müller, Spec. Pap. Geol. Soc. Am., 372, pp. 383-403, doi:10.1130/0-8137-2372-8.383.

Danyushevsky, L. V., A. J. Crawford, R. L. Leslie, S. Tetroeva, and T. J. Falloon (2005), Subduction-related magmatism along the southeast margin of the North Fiji backarc basin, Geochim. Cosmochim. Acta, 69, suppl.1, A633.

DeBari, S. M., B. Taylor, K. Spencer, and K. Fujioka (1999), A trapped Philippine Sea plate origin for MORB from the inner slope of the Izu-Bonin trench, Earth Planet. Sci. Lett., 174, 183-197, doi:10.1016/S0012-821X(99)00252-6.

Ewart, A., K. D. Collerson, M. Regelous, J. I. Wendt, and Y. Niu (1998), Geochemical evolution within the TongaKermadec-Lau Arc-Back-arc systems: The role of varying mantle wedge composition in space and time, J. Petrol., 39, 331-368, doi:10.1093/petroj/39.3.331.

Falloon, T. J., and A. J. Crawford (1991), The petrogenesis of high-calcium boninite lavas dredged from the northern Tonga ridge, Earth Planet. Sci. Lett., 102, 375-394, doi:10.1016/0012-821X(91)90030-L.

Falloon, T. J., S. H. Bloomer, and A. J. Crawford (1997), Boninites recovered from the Tonga Fore arc, Eos Trans. AGU, 78(46), Fall Meet. Suppl., F815.

Falloon, T. J., L. V. Danyushevsky, T. J. Crawford, R. Maas, J. D. Woodhead, S. M. Eggins, S. H. Bloomer, D. J. Wright, S. K. Zlobin, and A. R. Stacey (2007), Multiple mantle plume components involved in the petrogenesis of subduction-related lavas from the northern termination of the Tonga Arc and northern Lau Basin: Evidence from the geochemistry of arc and backarc submarine volcanics, Geochem. Geophys. Geosyst., 8, Q09003, doi:10.1029/2007GC001619.

Falloon, T. J., L. V. Danyushevsky, A. J. Crawford, S. Meffre, J. D. Woodhead, and S. H. Bloomer (2008), Boninites and adakites from the northern termination of the Tonga Trench: Implications for adakite petrogenesis, J. Petrol., 49, 697-715, doi:10.1093/petrology/egm080.

Hall, C. E., M. Gurnis, M. Sdrolias, L. L. Lavier, and R. D. Muller (2003), Catastrophic initiation of subduction following forced convergence across fracture zones, Earth Planet. Sci. Lett., 212(1-2), 15-30, doi:10.1016/S0012-821X(03) 00242-5.

Hall, R. (2002), Cenozoic geological and plate tectonic evolution of SE Asia and the SW Pacific: Computer-based reconstructions, model and animations, J. Asian Earth Sci., 20, 353-431, doi:10.1016/S1367-9120(01)00069-4.

Hawkins, J. W. (1994), Petrologic Synthesis: Lau Basin transect (Leg 135), Ocean Drill. Program Sci. Results, 135, pp. 879-905, doi:10.2973/odp.proc.sr.135.135.1994.
Hawkins, J. W., S. H. Bloomer, C. A. Evans, and J. T. Melchoir (1984), Evolution of intra-oceanic arc-trench systems, Tectonophysics, 102, 175-205, doi:10.1016/0040-1951(84)90013-1.

Herzer, R. H., D. H. N. Barker, W. R. Roest, and N. Mortimer (2011), Oligocene-miocene spreading history of the northern South Fiji Basin and implications for the evolution of the New Zealand plate boundary, Geochem. Geophys. Geosyst., 12, Q02004, doi:10.1029/2010GC003291.

Hickey-Vargas, R. (2005), Basalt and tonalite from the Amami Plateau, northern West Philippine Basin: New early cretaceous ages and geochemical results, and their petrologic and tectonic implications, Isl. Arc, 14, 653-665, doi:10.1111/ j.1440-1738.2005.00474.x.

Hickey-Vargas, R., M. Bizimis, and A. Deschamps (2008), Onset of the Indian Ocean isotopic signature in the Philippine Sea Plate: $\mathrm{Hf}$ and $\mathrm{Pb}$ isotope evidence from Early Cretaceous terranes, Earth Planet. Sci. Lett., 268, 255-267, doi:10.1016/ j.epsl.2008.01.003.

Ishikawa, T., K. Nagaishi, and S. Umino (2002), Boninitic volcanism in the Oman ophiolite: Implications for thermal condition during transition from spreading ridge to arc, Geology, 30, 899-902, doi:10.1130/0091-7613(2002)030<0899:BVI$\mathrm{TOO}>2.0 . \mathrm{CO} ; 2$

Ishizuka, O., K. Tani, M. K. Reagan, K. Kanayama, S. Umino, Y. Harigane, I. Sakamoto, Y. Miyajima, M. Yuasa, and D. J. Dunkley (2011), The timescales of subduction initiation and subsequent evolution of an oceanic island arc, Earth Planet. Sci. Lett., 306, 229-240, doi:10.1016/j.eps1.2011.04.006.

Johnson, L. E., P. Fryer, B. Taylor, M. Silk, D. L. Jones, W. V. Sliter, T. Itaya, and T. Ishii (1991), New evidence for crustal accretion in the outer Mariana fore arc: Cretaceous radiolarian cherts and mid-ocean ridge basalt-like lavas, Geology, 19, 811-814, doi:10.1130/0091-7613(1991)019<0811:NEF$\mathrm{CAI}>2.3 . \mathrm{CO} ; 2$.

Kelman, M. (1998), Hydrothermal alteration of a supra-subduction zone ophiolite analog, Tonga, southwest Pacific, M.Sc thesis, 193 pp., Oreg. State Univ., Corvallis.

Koppers, A. A. P., R. A. Duncan, and B. Steinberger (2004), Implications of a nonlinear $40 \mathrm{Ar} / 39 \mathrm{Ar}$ age progression along the Louisville seamount trail for models of fixed and moving hot spots, Geochem. Geophys. Geosyst., 5, Q06L02, doi:10.1029/ 2003GC000671.

McDougall, I. (1994), Dating of rhyolitic glass in the Tonga fore arc (Hole 841B), Ocean Drill. Program Sci. Results, 135, 923, doi:10.2973/odp.proc.sr.135.140.1994.

Meffre, S., and T. J. Falloon (2007), Age and location of the initiation of the Tonga-Kermadec arc system, paper presented at 4th Asia Oceania Geosciences Society Conference, Bangkok.

Meffre, S., J. C. Aitchison, and A. J. Crawford (1996), Geochemical evolution and tectonic significance of boninites and tholeiites from the Koh ophiolite New Caledonia, Tectonics, 15, 67-83, doi:10.1029/95TC02316.

Monzier, M., L. V. Danyushevsky, A. J. Crawford, H. Bellon, and J. Cotten (1993), High-Mg andesites from the southern termination of the New Hebrides island arc (SW Pacific), J. Volcanol. Geotherm. Res., 57, 193-217, doi:10.1016/ 0377-0273(93)90012-G.

Mortimer, N., R. H. Herzer, P. B. Gans, C. Laporte-Magoni, A. T. Calvert, and D. Bosch (2007), Oligocene-Miocene tectonic evolution of the South Fiji Basin and Northland Plateau, SW Pacific Ocean: Evidence from petrology and dating of dredged rocks, Mar. Geol., 237, 1-24, doi:10.1016/j. margeo.2006.10.033. 
Nicholson, K. N., C. Picard, and P. M. Black (2000a), A comparative study of Late Cretaceous ophiolitic basalts from New Zealand and New Caledonia: Implications for the tectonic evolution of the SW Pacific, Tectonophysics, 327, 157-171, doi:10.1016/S0040-1951(00)00167-0.

Nicholson, K. N., P. M. Black, and C. Picard (2000b), Geochemistry and tectonic significance of the Tangihua Ophiolite Complex, New Zealand, Tectonophysics, 321, 1-15, doi:10.1016/S0040-1951(00)00081-0.

Reagan, M. K., et al. (2010), Fore arc basalts and subduction initiation in the Izu-Bonin-Mariana system, Geochem. Geophys. Geosyst., 11, Q03X12, doi:10.1029/2009GC002871.

Rey, P. F., and R. D. Muller (2010), Fragmentation of active continental plate margins owing to the buoyancy of the mantle wedge, Nat. Geosci., 3, 257-261, doi:10.1038/ngeo825.

Sack, P. J., R. F. Berry, S. Meffre, T. J. Falloon, J. B. Gemmell, and R. M. Friedman (2011), In situ location and U-Pb dating of small zircon grains in igneous rocks using laser ablationinductively coupled plasma-quadrupole mass spectrometry, Geochem. Geophys. Geosyst., 12, Q0AA14, doi:10.1029/ 2010GC003405.

Schellart, W. P., and W. Spakman (2012), Mantle constraints on the plate tectonic evolution of the Tonga-Kermadec-Hikurangi subduction zone and the South Fiji Basin region, Aust. J. Earth Sci., 59, 933-952, doi:10.1080/08120099.2012.679692.

Schellart, W. P., G. S. Lister, and V. G. Toy (2006), A Late Cretaceous and Cenozoic reconstruction of the Southwest Pacific region: Tectonics controlled by subduction and slab rollback processes, Earth Sci. Rev., 76, 191-233, doi:10.1016/j. earscirev.2006.01.002.

Seton, M., C. Gaina, R. D. Mueller, and C. Heine (2009), Mid-Cretaceous seafloor spreading pulse: Fact or fiction?, Geology, 37, 687-690, doi:10.1130/G25624A.1.

Sinton, J. M., and P. Fryer (1987), Mariana Trough lavas from $18^{\circ} \mathrm{N}$ : Implications for the origin of back arc basin basalts, J. Geophys. Res., 92, 12,782-12,802, doi:10.1029/ JB092iB12p12782.

Stern, R. J. (2004), Subduction initiation: Spontaneous and induced, Earth Planet. Sci. Lett., 226, 275-292, doi:10.1016/ j.eps1.2004.08.007.

Stern, R. J., and S. H. Bloomer (1992), Subduction zone infancy: Example from the Eocene Izu-Bonin-Mariana and Jurassic California arcs, Geol. Soc. Am. Bull., 104, 1621-1636, doi:10.1130/0016-7606(1992)104<1621:SZIEFT>2.3.CO;2.
Sun, S. S., and W. F. McDonough (1989), Chemical and isotopic systematics of oceanic basalts: Implications for mantle composition and processes, in Magmatism in the Ocean Basins, edited by A. D. Saunders and M. J. Norry, Geol. Soc. Spec. Publ., 42, 313-345.

Tappin, D. (1996), Site survey on RV Melville: Boomerang leg 8, May-June 1996, SOPAC Rep. 146, 4 pp., South Pac. Appl. Geosci. Comm., Fiji. [Available at ict.sopac.org/VirLib/ CR0146.pdf.]

Todd, E., J. B. Gill, and J. A. Pearce (2012), A variably enriched mantle wedge and contrasting melt types during arc stages following subduction initiation in Fiji and Tonga, southwest Pacific, Earth Planet. Sci. Lett., 335-336, 180-194, doi:10.1016/j.epsl.2012.05.006.

Toth, J., and M. Gurnis (1998), Dynamics of subduction initiation at preexisting fault zones, J. Geophys. Res., 103, 18,053-18,067, doi:10.1029/98JB01076.

Whattam, S. A. (2009), Arc-continent collisional orogenesis in the SW Pacific and the nature, source and correlation of emplaced ophiolitic nappe components, Lithos, 113, 88-114, doi:10.1016/j.lithos.2008.11.009.

Whattam, S. A., and R. J. Stern (2011), The 'subduction initiation rule': A key for linking ophiolites, intra-oceanic fore arcs, and subduction initiation, Contrib. Mineral. Petrol., 162, 1031-1045, doi:10.1007/s00410-011-0638-z.

Whattam, S. A., J. Malpas, J. R. Ali, and I. E. M. Smith (2008), New SW Pacific tectonic model: Cyclical intraoceanic magmatic arc construction and near-coeval emplacement along the Australia-Pacific margin in the Cenozoic, Geochem. Geophys. Geosyst., 9, Q03021, doi:10.1029/2007GC001710.

Wiedenbeck, M., P. Alle, F. Corfu, W. Griffin, and M. Meier (1995), Three natural zircon standards for the U-Th-Pb, Lu-Hf, trace element and REE analyses, Geostand. Newsl., 19, 1-23, doi:10.1111/j.1751-908X.1995.tb00147.x.

Wright, D. J., S. H. Bloomer, and the Boomerang 8 Party (1996), New SeaBeam 2000 bathymetry and sidescan data from the Tonga fore arc and trench; results from Boomerang Leg 8, an ODPSite survey, Eos Trans. AGU, 77, 326.

Wright, D. J., S. H. Bloomer, C. J. MacLeod, B. Taylor, and A. M. Goodlife (2000), Bathymetry of the Tonga Trench and Fore arc: A map series, Mar. Geophys. Res., 21, 489-512, doi:10.1023/A:1026514914220. 